Participatory Educational Research (PER)

Special Issue 2015-II, pp., 1-9; 5-7 November, 2015

Available online at http://www.partedres.com

ISSN: 2148-6123

http://dx.doi.org/10.17275/per.15.spi.2.1

\title{
Research of Distance Education Students Cloud Perceptions and Use Cases
}

\author{
Hakan KÖR * \\ Distance Education Center, Hitit University, Çorum, Turkey
}

Hasan ERBAY

Engineering Faculty, Computer Engineering, Kırkkkale University, Kırlkkale, Turkey

\author{
Emre DEMIR \\ Medicine Faculty, Hitit University, Çorum, Turkey
}

\begin{abstract}
There are 193 universities, including government and private, in Turkish higher education system. According to the 2014-15 the academic year statistics issued by the Higher Education Council, there are 2.013.672 students in associate programs whereas 3.628.800 students in bachelor degrees. Together with students from graduate degree programs, there are about six million students within Turkish higher education system. Besides, 150,000 academic personnel are employed for maintenance of education activities in higher education. This situation increases the demand on the information technologies. Nowadays, expanding areas of cloud computing such as storage, software, database, and hardware sharing are at the forefront. In addition, the cloud computing technology provides great contributions to educational activities. Within the education process in Turkey, only few researches have been conducted to determine the level of awareness toward cloud computing technology. In this study, perceptions of students and faculty members in the higher education toward the cloud computing and their usage levels were investigated. At the first stage, by consulting to experts opinions, a survey form was created and implemented to measure participants' perception and usage status regarding cloud perception. The research sample is consisted of students and faculty members of the Hitit University. As data collected through the survey method, obtained data was processed and analyzed by SPSS Software and the relevant findings were summarized in the finding section. In further studies, it is planned to extend the study over various sampling groups from different universities.
\end{abstract}

Keyword: Cloud Computing, Distance Education, Cloud Computing Perception

\section{Introduction}

"Cloud computing" is one of the computer science areas which has been influenced by fast-paced technological advancements. Cloud computing technology utilizes from internet and distance central servers for data supply and applications. By means of cloud computing, consumers and businesses can have access into their private files without setting up applications through a computer connected into internet. Owing to this technology, faster data

\footnotetext{
* Correspondence: hakankor19@gmail.com
} 
computing, storage and band-width can be ensured through central data storage (Bora and Ahmed, 2013).

Cloud computing concept that has been known for a considerable time has gained extensive application areas in countries with superior internet infrastructure and speed. Similarly, owing to progress in internet speed in Turkey, accordingly cloud computing concept came to prominence in public and private organizations in recent years. Today, majority of organizations fulfill their needs by means of cloud computing-based solution providers instead of making huge investments in computer hardware, software, platform and storage. Cloud computing concept and applications have especially started to find place in educational institutions such as computer technology departments of universities remarkably.

\section{Development of Cloud Technology}

Although origin of the cloud computing term is not clear, it can be traced back until 1950s. Time sharing concept which is known to be originated from high cost of computers was being applied in the past for hardware and processor share. Along the time, accompanying with increasing number of computer and internet user, decreasing costs in computing industry has further developed cloud computing concept. Development table of cloud computing is exhibited in Table 1

\section{Development of Cloud Computing in the History}

According to Table 1, cloud computing concept, which has physically commenced with sharing of computers, today offers storage, e-mail services, mutual usage of software, and simultaneous access to information and allows saving from cost, labor, enhances security and utility of information to their users.

Table 1. Historical Development of Cloud Computing (Wikipedia, 2015)

\begin{tabular}{ll}
\hline Date & Development \\
\hline $1950 \mathrm{~s}$ & $\begin{array}{l}\text { Large-scale servers at universities and companies were accessed by considerably } \\
\text { weak terminals/clients. }\end{array}$ \\
\hline \multirow{2}{*}{$1960 \mathrm{~s}$} & $\begin{array}{l}\text { John McCarthy foresaw that computing technology will be organized in the future } \\
\text { like public electric and water utilities in 1960s. }\end{array}$ \\
\hline $1970 \mathrm{~s}$ & Time sharing concept has arisen (Strachey, 1959). \\
\hline \multirow{2}{*}{$1990 \mathrm{~s}$} & $\begin{array}{l}\text { In order to provide well-balanced band-width, telecommunication companies started } \\
\text { to build virtual private networks (VPN) through point-to-point electric circuits. }\end{array}$ \\
\hline & $\begin{array}{l}\text { 2002: Amazon web service. } \\
\text { 2006: Amazon s3. the first real cloud application. }\end{array}$ \\
& $\begin{array}{l}\text { 2007-2008: Google and IBM created cloud service (Sevli, 2011). } \\
\text { July 2010: Rackspace Hosting and NASA initiated an open-source cloud software } \\
\text { entrepreneur which is known as Open Stack jointly. } \\
\text { March 2011: IBM company introduced smart cloud framework. } \\
\text { June 2012: Oracle company introduced Oracle Cloud. }\end{array}$ \\
\end{tabular}

\section{Cloud Service Supplying Models}

A cloud can interact with user or applications and this process is referred as service. There four different distributions models for cloud computing in internet: Infrastructure (IaaS), Platform (Paas), Software and other models (Baun et al, 2011).

(IaaS) - Infrastructure as a Service: This cloud model is preferred by users for services such as data storage, memory and band width. In other words, this model provides hardware infrastructure to users without spending any effort in the exchange for certain cost. 
(PaaS) - Platform as a Service: This service model is established on the Iass; and the target is not end users, but developers. In this service, programming and operation environments and special programming languages can be run. Platform cloud service providers supply solutions to their users for network support, database and operation system usage by means of internet. Microsoft Windows Azure and Google App Engine Paas can be displayed as examples of service model commercial applications (Caytileset al (2012) and Omotunde et al, (2013)).

(Saas) - Software as a Service: This cloud service offers cloud-based software and applications to end users or organizations request service over network. Users gain access to the services about which they make payment. Advantages of these services are that user can have access into service software by means of a web browser; and can use data center in the cloud for affordable price. Popular software cloud services are Gmail, Google Docs, Exchange online Business Productivity Online Suite, CRM Online and Salesforce.com (Omotunde et al, (2013) and Ibikunle et al, (2011)).

\section{Cloud Application Distribution Models}

Private Cloud: This model is the one created by the organization or leased. Created system can only be used by the organization itself.

Public Cloud: This cloud is structured for public services. They provide services like software and storage open to everyone. In comparison with other clouds, their costs are less (Şanl1, 2011). Amazon EC2. S3. Google AppEngine and Force.com are examples of public cloud examples.

Hybrid Cloud: This model is structured by integration of two or more cloud models. Clouds, without losing their unique characteristics, are structured in a way that software and data are allowed to be transmitted, or integrated through special technological methods. A hybrid cloud controls planned work load points (Sun Microsystems, 2009).

Community Cloud: Cloud infrastructure is shared with certain society. This model can be shared by private or government institution; thus, institutions with mutual targets, which need similar security protocols, and administered similarly, are supported.

\section{Cloud Applications in Education}

It has been observed that technological advancement along the last 15 years, especially afterwards of 2000. has found application areas in education domain; and that it introduced innovative applications in current education and teaching strategy and methods. As information society, when learning needs are taken into consideration, it is possible state that fast-access to information from anywhere and anytime, and learning when it is needed have gained prominence. Learning requirements which arise independent of space and time, has resulted in "mobile learning" education model. In our contemporary world, this new learning model has allowed education to gain a brand new dimension and pace. By facilitating accessing information on the move when it is needed, innovative strategies, methods and learning approaches have been introduced to education-teaching programs (Çakır, 2011).

Computing technologies owned and utilized by private organizations or government institutions go out of date after a certain period; and this requires investments in to new 
infrastructures. However, whereas cloud computing-based systems reduce computing infrastructure investment costs of organizations, they offer more flexible software and hardware options (Sarıtaş ve Üner, 2013). In other words, by means of cloud computing infrastructure, the necessity to make continuous investment in education is eliminated and it would be possible to reach software licenses and faster hardware resources with less cost (Sevli, 2013).

Although Google Apps is hosting numerous applications inside, Gmail, Calendar, Google Drive, Google Documents, Google E-tables, Google Slides, Google Sites and Google Translation can also be utilized for education purposes (Google Apps, 2015).

\section{Method}

In the present study, a survey was conducted on distance education students in order to determine their perception and usage status; and obtained data was analyzed by means of the SPSS Package Software.

\section{Sampling}

The research sampling consists of 721 students from 12 different academic divisions: 4 faculties, 2 colleges, and 6 vocational schools, and who are registered with distance learning center at the Hitit University during fall semester of the 2015-2016 academic calendar.

\section{Data Collection and Data Analysis}

The relevant survey was applied to Hitit University students through an online application. From the Google platform, it was ensured that each user can only participate in survey once. Information collected from 721 students who answered all questions in the form was analyzed by means of descriptive statistics, correlation, T-test and One-Way ANOVA analyses and findings were summarized in the results sections.

\section{Results}

According to Table 2, it can be observed that mean age of participant students is 20.85 \pm 4.246 .

Table 2. Age Distribution of Participant Students

\begin{tabular}{lllll}
\hline \multicolumn{4}{c}{ Age } \\
\hline $\mathrm{N}$ & Minimum & Maximum & Mean & Std. Deviation \\
721 & 15 & 65 & 20.85 & 4.246 \\
\hline
\end{tabular}

According to Table 3, with respect to gender of participant students, it can be observed that whereas 338 students were male $(53.8 \%), 333$ students were female $(46.2 \%)$

Table 3. Gender Distribution of Participant Students

\begin{tabular}{lcccc}
\hline \multicolumn{5}{c}{ Gender } \\
\hline \multirow{3}{*}{ Male } & Frequency & Percent & Valid Percent & Cumulative Percent \\
Female & 388 & 53.8 & 53.8 & 53.8 \\
& 333 & 46.2 & 46.2 & 100.0 \\
\hline
\end{tabular}


According to Table 4, when residential places of participant students together with their parents are taken into consideration, it is remarkable that whereas $27.7 \%$ were in cities, $39 \%$ were in metropolitans.

Table 4. Residential Places of Participant Students

\begin{tabular}{lcc}
\hline & Frequency & Percent \\
\hline Village- Town & 66 & 9.2 \\
Municipality & 11 & 1.5 \\
County & 163 & 22.6 \\
City & 200 & 27.7 \\
Metropolitan & 281 & 39.0 \\
\hline
\end{tabular}

According to Table 5, of the participant students, while $63.9 \%$ have personal computer, $36.1 \%$ do not.

Table 5. Have a Computer of Participant Students

\begin{tabular}{lll}
\hline & Frequency & Percent \\
\hline No & 260 & 36,1 \\
Yes & 461 & 63,9 \\
\hline
\end{tabular}

According to Table 6. when devices are taken into consideration from where/which students gain access to internet, it can be observed that $50.9 \%$ were from smart phones, $24.5 \%$ were from laptops.

Table 6. Devices used by students to access into internet.

\begin{tabular}{lcc}
\hline Devices & Frequency & Percent \\
\hline Smart Phone & 367 & 50.9 \\
Laptop & 177 & 24.5 \\
Tablet & 34 & 4.7 \\
Desktop & 61 & 8.5 \\
Other & 82 & 11.4 \\
\hline
\end{tabular}

According to Table 7, when students' answers given to the question of "do you actively use cloud service?" are taken into consideration, it can be seen that almost half of students uses a cloud storage service.

Table 7. Active Cloud Service Usage Rates of Students

\begin{tabular}{cll}
\hline & Frequency & Percent \\
\hline Yes & 380 & 52.7 \\
No & 341 & 47.3 \\
\hline
\end{tabular}

According to Table 8, it can be observed that students mostly use Google drive cloud service for data storage; secondly they prefer yandisk cloud storage service.

Table 8. Cloud Services Used for Data Storage

\begin{tabular}{lll}
\hline Cloud Service & Frequency & Percent \\
\hline Yandisk & 261 & 36.2 \\
One Drive & 40 & 5.5 \\
Google drive & 287 & 39.8 \\
Dropbox & 19 & 2.6 \\
Mega & 19 & 2.6 \\
\hline
\end{tabular}




\begin{tabular}{ccc}
\hline Other & 95 & 13.2 \\
\hline
\end{tabular}

According to Table 9, it can be seen that whereas about $31.5 \%$ of students use a cloud service; $68.5 \%$ do not.

Table 9. Cloud Computing Service Usage Rates (Such as Office 365, Adobe Creative Cloud)

\begin{tabular}{lll}
\hline & Frequency & Percent \\
\hline Yes & 227 & 31.5 \\
No & 494 & 68.5 \\
\hline
\end{tabular}

In Table 10, students cloud score and basic computer knowledge scores were exhibited. While cloud score is determined by totally 7 questions; its mean score is estimated as 22.12. Whereas basic computer score is determined by totally 8 questions, its mean score is estimated as 22.7 .

Table 10. Cloud Score and Basic Computer Knowledge Scores

\begin{tabular}{llllll}
\hline & $\mathrm{N}$ & Minimum & Maximum & Mean & Std. Deviation \\
\hline Basic computer scores & 721 & 8.00 & 40.00 & 26.0444 & 5.86356 \\
Cloud scores & 721 & 7.00 & 35.00 & 22.1234 & 3.40873 \\
\hline
\end{tabular}

Before, t-test and one way ANOVA analyses, Cronbach's Alpha reliability value was estimated and displayed in Table 11. This finding suggests that survey has high reliability.

Table 11. Reliability Test

\begin{tabular}{|c|c|c|}
\hline \multicolumn{2}{|c|}{$\begin{array}{l}\text { Cronbach's Alpha } \\
0.914\end{array}$} & \\
\hline \multicolumn{3}{|c|}{$\begin{array}{l}\text { able } 12 \text {, it is possible to } \\
\text { ven though it is slightly. }\end{array}$} \\
\hline \multicolumn{3}{|c|}{ 12. Basic Computer and Cloud Scores } \\
\hline & Basic computer score & Cloud score \\
\hline on Coefficient & 1.000 & $\mathrm{r}=0.336 * *$ \\
\hline iled) & .000 & $\mathrm{P}=0.000$ \\
\hline & 721 & 721 \\
\hline
\end{tabular}

If plotted graphic, which exhibits the correlation between cloud score and basic computer score, given in Figure 1 is considered, it can be observed that there is proportional correlation between these values. 


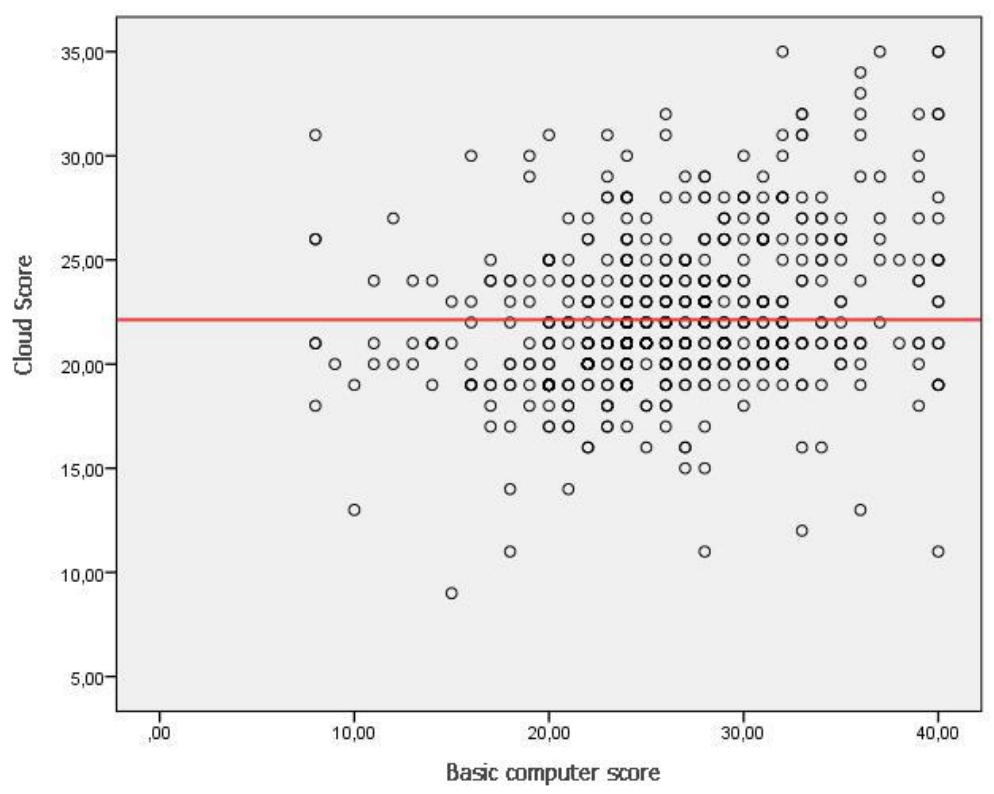

Figure 1. Compare of Cloud Score-Basic Computer Score

According to Table 13, it was determined that $\mathrm{p}=0.10<0.05$. Accordingly, it was determined that there is significant difference between mean scores of having a personal computer and using cloud.

Table 13. Correlation Between Using Cloud Score and Having Personal Computer

\begin{tabular}{|c|c|c|c|c|c|}
\hline & Do you have a PC? & $\mathrm{N}$ & Mean & Std. Dev. & Std. Error Mean \\
\hline \multirow[t]{2}{*}{ Cloud score } & No & 260 & 21.6885 & 3.39644 & .21064 \\
\hline & Yes & 461 & 22.3688 & 3.39479 & .15811 \\
\hline
\end{tabular}

According to Table 14, it was determined that $\mathrm{p}=0<0.05$. Accordingly, it was determined that there is significant difference between students' mean scores of cloud service usage and cloud service.

Table 14. Cloud Service Usage Status of Students

\begin{tabular}{llllll}
\hline & $\begin{array}{l}\text { Do you use cloud } \\
\text { service? }\end{array}$ & $\mathrm{N}$ & Mean & Std. Deviation & Std. Error Mean \\
\hline \multirow{2}{*}{ Cloud score } & Yes & 227 & 23.8106 & 3.83905 & .25481 \\
& No & 494 & 21.3482 & 2.88105 & .12962 \\
\hline
\end{tabular}

According to Table 15 , since $\mathrm{p}=0.190>0.05$, it can be seen that there is no statistically significant difference between student gender and their cloud mean scores.

Table 15. Correlation Between Students' Cloud Score and Their Gender

\begin{tabular}{llllll}
\hline & Gender? & $\mathrm{N}$ & Mean & Std. Deviation & Std. Error Mean \\
\hline Cloud Score & Male & 388 & 21.9691 & 3.25316 & .16515 \\
& Bayan & 333 & 22.3033 & 3.57803 & .19607 \\
\hline
\end{tabular}


According to Table 16 , since $\mathrm{p}=0.526>0.05$, it can be observed that there is no statistically significant relationship between students' ages and their cloud scores.

Table 16. Correlation Between Students' Ages and Their Cloud Scores

\begin{tabular}{lll}
\hline \multicolumn{2}{c}{ Correlations } \\
\hline \multirow{3}{*}{ Age } & Pearson Correlation & Cloud Score \\
& Sig. (2-tailed) & -.024 \\
& $\mathrm{~N}$ & .526 \\
& 721 \\
\hline
\end{tabular}

According to Table 17, it was determined that $\mathrm{p}=0.336>0.05$. Accordingly, it can be seen that residential places of students are not significantly effective on their mean cloud scores.

Table 17. Correlation Between Residential Places of Students and Their Mean Cloud Score

\begin{tabular}{lllllll}
\hline \multicolumn{7}{c}{ Cloud score } \\
\hline & & & & & \multicolumn{2}{l}{$95 \%$ Confidence Interval for } \\
Mean & \\
Village/Town & $\mathrm{N}$ & Mean & Std. Deviation & Std. Error & Lower Bound & Upper Bound \\
Municipality & 66 & 21.7576 & 3.70472 & .45602 & 20.8468 & 22.6683 \\
County & 11 & 21.1000 & 2.60128 & .82260 & 19.2392 & 22.9608 \\
City & 163 & 22.2716 & 3.52458 & .27692 & 21.7247 & 22.8185 \\
Metropolitan & 200 & 21.8442 & 3.07496 & .21798 & 21.4144 & 22.2741 \\
& 281 & 22.3536 & 3.52665 & .21076 & 21.9387 & 22.7684 \\
\hline
\end{tabular}

\section{Discussion}

According to study results, it is possible to observe that majority of students live in cities and metropolitan areas; more than half has a computer; almost half uses a cloud system for data storage purposes; and usage rate of uncommon and special cloud services is around $30 \%$.

Moreover, a significant correlation was determined between students' cloud computing scores and their gender, age and residential place variables.

Based on study results, there is statistical difference between basic mean computer usage score and mean cloud score; but this is rather at low level.

Moreover, it was observed that cloud scores of students using cloud services previously or currently were higher with respect to others.

According to these results, students mostly use cloud services for data storage purposes. Portion of students who use other (e.g. Office 365, Adobe Creative Cloud, and etc.) cloud services is about $30 \%$.

In this regard, it can be concluded that students is not much stranger to cloud computing concept. Moreover, especially in our contemporary time in which internet access opportunities and relevant devices are extensively used, utilization from cloud services in available infrastructure will allow organizations to save from their costs and labor and to 
manage vast amount of data while they facilitate access of users into internet and increase access speed.

\section{References}

Baun C.,Kunze M., Nimis J., and Tai S.(2011). Cloud Computing Web-Based Dynamic IT Services, in Cloud Computing, pp. 15-22, Springer Berlin Heidelberg.

Bora U. J., Ahmed M. (2013). E-Learning using Cloud Computing. International Journal of Science and Modern Engineering (IJISME), 1(2), 9-13.

Caytiles R.D., Lee S., and Park B.(2012). Cloud Computing: The Next Computing Paradigm, International Journal of Multimedia and Ubiquitous Engineering, 7(2), pp. 297302, South Korea.

Çakır, H,. Mobil öğrenmeye ilişkin bir yazılım geliştirme ve değerlendirme. Çukurova Üniversitesi Eğitim Fakültesi Dergisi, 2(40), 1-9, 2011, Adana.

Google Apps (2015). The tools your students want. Available at: http://www.google.com/enterprise/apps/education/products.html. Accessed: 19.01.2015.

Ibikunle F., Awodele O. and Kuyoro S.O. (2011). "Cloud Computing Security Issues and Challenges", International Journal of Computer Networks (IJCN), 3(5), pp. 247-225, Kuala Lumpur Malaysia.

Omotunde A.A., O Awodele , S. O Kuyoro , and C Ajaegbu., (2013). Survey of Cloud Computing Issues at Implementation Level, Journal of Emerging Trends in Computing and Information Sciences , 4(1), Canada.

Sarıtaş, T. and Üner N. (2013). Eğitimdeki Yenilikçi Teknolojiler: Bulut Teknolojisi, Eğitim ve Öğretim Araştırmaları Dergisi, 2(3), Mersin.

Sevli, O. (2011). Bulut bilişim ve eğitim alanında örnek bir uygulama. Yayımlanmamış yüksek lisans tezi, Süleyman Demirel Üniversitesi, Isparta

Sevli, O. (2013), Bulut Bilişimin Bireysel Kullanımı İçin Örnek Bir Uygulama, Akademik Bilişim, 2013, Mersin

Strachey, Christopher (June 1959). "Time Sharing in Large Fast Computers". Proceedings of the International Conference on Information processing, UNESCO. paper B.2.19: 336-341.

Sun Microsystems, Inc., Introduction to Cloud Computing Architecture, white paper 2009.

Şanlı, O.(2011). Bulut Bilişim, Akademik Bilişim, 2011, Malatya.

Wikipedia (2015). Available at: http://en.wikipedia.org/wiki/cloud_computing\#history, Accessed: 18.01.2015. 